\title{
Compression Method in the Complex Treatment of Bleeding Haemorrhoids
}

\author{
Alfazzaman $\mathrm{M}^{1}$, Anwary $\mathrm{SA}^{2}$, Rahman $\mathrm{MM}^{3}$, Islam $\mathrm{MR}^{4}$
}

\begin{abstract}
This study was designed to find out the effectiveness of compressive method with the combined surgical treatment of bleeding haemorrhoids. A total of 80 patients with bleeding haemorrhoids were equally divided into two groups: case $(n=40)$ and control $(n=40)$, and underwent haemorroidectomy by modified Milligan Morgan method at the Department of Clinical Surgery, Russian Peoples' Friendship University Hospital No. 17, Moscow, Russia, during January 1992 and December 2001. In case group, after operation, compressive probe was applied in the anorectum with inflated balloon at the place of external and internal haemorrhoidal sites, but in the control group, antibacterial ointment soaked tampon was introduced into the anorectum. At 1st after operation, in case and control group, respectively, pain at operation site was present in $30 \%$ and $47.5 \%$, pain in anorectum during defaecation in $42.5 \%$ and $72.5 \%$, retention of urine in $5 \%$ and $20 \%$, and periodic bleeding at defaecation in $5 \%$ and $20 \%$. At 2 nd week after operation, adaptation of edge of sutured mucosa was satisfactory in $20 \%$ and $87.5 \%$, and good in $92.5 \%$ and $35 \%$; and normalization of stool was seen in $87.5 \%$ and $62.5 \%$ patients, respectively. None in case group required blood transfusion versus $22.5 \%$ in control group. Hospital stay $6.83 \pm 0.98$ vs $12.30 \pm 1.54$ days (case and control). Compressive method provides elimination of stagnation of blood in the cavernous derivations resulting in fall and aseptic pasting together of their walls, sclerosis and shrinkage of haemorrhoidal clusters, resulting in the prevention of relapse of haemorrhoids.
\end{abstract}

Key words: Bleeding haemorrhoids, Haemorrhoidectomy, Compression method.

\section{Introduction}

Haemorrhoids is one of the most widespread disease of anorectum. According to the various statistics, its frequency among the adult population varies within the limits of 60$70 \%$. According to the data, absolute increase of this pathology, only in Russia annually 600,000 patients are hospitalized with haemorrhoids. A large number of patients

1. Corresponding Author: Dr. Md. Alfazzaman Assistant Professor, Department of Surgery Z.H. Sikder Women's Medical College, Dhaka

2. Dr. Shaheen Ara Anwary Assistant Professor, Department of Obstetrics and Gynaecology Bangabandhu Sheikh Mujib Medical University, Dhaka

3. Dr. Md. Mujibur Rahman Associate Professor and Head, Department of Urology Z.H. Sikder Women's Medical College, Dhaka

4. Professor Dr. Md. Rezaul Islam Professor and Head, Department of Anaesthesiology Z.H. Sikder Women's Medical College, Dhaka receiving an outpatient treatment or engaging a self treatment are not included in the statistics ${ }^{2}$. Among the patients, the majority are from the working age group 3065 years. Taking into account that for $29-90 \%$ of these patients encounter from two up to six episodes per year, and for each episode loss of working days range 6-35 days. Therefore, haemorrhoids represent an important social problem ${ }^{3}$.

The diversity of methods of treatment of haemorrhoids gives evidence to a high prevalence of this disease and calls doubts about the efficiency of its treatment. All the known methods of now a days have side effects, still there are complications and lethal outcomes ${ }^{4,6}$. Compression method was used effectively in bleeding haemorrhoids as part of conservative treatment in the patients in whom general or spinal anaesthesia was contraindicated ${ }^{7}$. Surgical treatment of haemorrhoids, especially the bleeding haemorrhoids is a concern of the colorectal surgeons and this articles shows the effectiveness of compression method with the combined surgical treatment of bleeding haemorrhoids.

\section{Materials and Methods}

The study was carried out in the Department of Clinical Surgery of Russian Peoples' Friendship University at the hospital No. 17 in Moscow city, during the period from January 1992 to December 2001. Eighty patients with bleeding haemorrhoids were included in this study. Among them, 40 were in the case group and 40 in the control group. Ethical clearance for this study was obtained from the concerned university and from the director of the hospital No. 17 and written consents all patients were also obtained.

Inclusion criteria were bleeding haemorrhoids along with rectal polyp, anal fissure, anal stenosis, prolapse and mucosa, and condyloma of anus. Exclusion criteria were patients with per rectal bleeding having rectal carcinoma histologically confirmed along with haemorrhoids.

All 80 patients underwent haemorrhoidectomy by modified Milligan Morgan method. After operation, in the case group compressive probe was applied in the anorectum with inflated balloon ( $50 \mathrm{mmHg}$ in each balloon) at the place of external and internal haemorrhoidal sites for 24 hours; whereas in the control group, at the end of operation, after haemostasis, antibacterial ointment soaked tampon was introduced into the anorectum.

\section{Results}

Table I shows patient data. Mean $( \pm S D)$ age showed no significant difference between case $(42.70 \pm 7.88$ years $)$ and control (43.55 \pm 6.72 years) groups. Sex also showed no significant variation between groups. In case and control group, respectively, there were $28(70 \%)$ and $26(65 \%)$ male, and $12(30 \%)$ and $14(35 \%)$ female. 
Associated diseases in control and case group of patients were polyp of anal canal (10\% and $20 \%)$, anal fissure $(2.5 \%$ each), anal stenosis (7.5\% and $2.5 \%)$, condyloma of anus (2.5\% each), prolapse of anal mucosa (10\% and $0 \%)$ and none $(67.5 \%$ and $72.5 \%)$. Distribution of associated diseases between groups statistically showed no significant variation.

None of the patient of case group required blood transfusion, however, 9 (22.5\%) patients from control group required blood transfusion $(\mathrm{P}<0.01)$.

Mean $( \pm \mathrm{SD})$ hospital stay was significantly high $(\mathrm{P}<0.001)$ in control group of patients compared to case $(12.30 \pm 1.54$ and $6.83 \pm 0.98$ days).

Table I: Patient data

\begin{tabular}{|c|c|c|c|c|c|}
\hline Variables & \multicolumn{2}{|c|}{$\begin{array}{l}\text { Case } \\
(n=40)\end{array}$} & \multicolumn{2}{|l|}{$\begin{array}{l}\text { Control } \\
(n=40)\end{array}$} & P value \\
\hline \multicolumn{6}{|l|}{ Age (years) } \\
\hline \multirow[t]{2}{*}{ Mean \pm SD } & \multicolumn{2}{|c|}{$42.70 \pm 7.88$} & \multicolumn{2}{|c|}{$43.55 \pm 6.71$} & $0.605 n s$ \\
\hline & No. & $(\%)$ & No. & $(\%)$ & $P$ value \\
\hline Sex & & & & & $0.633 \mathrm{~ns}$ \\
\hline Male & 28 & $(70.0)$ & 26 & $(65.0)$ & \\
\hline Female & 12 & $(30.0)$ & 14 & $(35.0)$ & \\
\hline Associate diseases & & & & & $0.269 \mathrm{~ns}$ \\
\hline Polyp of anal canal & 4 & $(10.0)$ & 8 & $(20.0)$ & \\
\hline Anal fissure & 1 & $(2.5)$ & 1 & $(2.5)$ & \\
\hline Anal stenosis & 3 & $(7.5)$ & 1 & $(2.5)$ & \\
\hline Condyloma of anus & 1 & $(2.5)$ & 1 & $(2.5)$ & \\
\hline $\begin{array}{l}\text { Prolapse of anal } \\
\text { mucosa }\end{array}$ & 4 & $(10.0)$ & 0 & & \\
\hline None & 27 & $(67.5)$ & 29 & $(72.5)$ & \\
\hline Blood transfusion & & & & & $0.001 * *$ \\
\hline Required & 0 & & 9 & $(22.5)$ & \\
\hline Not required & 40 & $(100.0)$ & 31 & $(77.5)$ & \\
\hline \multicolumn{6}{|l|}{ Hospital stay (days) } \\
\hline Mean \pm SD & 6.83 & 0.98 & 12.3 & \pm 1.54 & $0.0001 * * *$ \\
\hline
\end{tabular}

Unpaired Student's 't' test/Chi square test $\mathrm{ns}=$ Not significant, $* *=$ Significant $(\mathrm{P}<0.01)$

$* * *=$ Significant $(\mathrm{P}<0.001)$

Table II shows status of preoperative and postoperative status of haemoglobin. In case and control groups, respectively, mean $( \pm \mathrm{SD})$ preoperative haemoglobin was $13.04 \pm 0.56$ and $12.57 \pm 0.80 \mathrm{~g} / \mathrm{dl}(\mathrm{P}<0.01)$, and postoperative was $12.84 \pm 0.56$ and $11.23 \pm 1.00 \mathrm{~g} / \mathrm{dl}(\mathrm{P}<0.001)$. Mean change of haemoglobin level at postoperative from preoperative level in case group was $0.20(1.54 \%)$ and in control group was 1.34 (10.73\%).

\section{Table II: Status of haemoglobin}

\begin{tabular}{|llll|}
\hline $\begin{array}{l}\text { Haemoglobin } \\
(\mathbf{g} / \mathbf{d l})\end{array}$ & $\begin{array}{l}\text { Case } \\
(\mathbf{n}=\mathbf{4 0})\end{array}$ & $\begin{array}{l}\text { Control } \\
(\mathbf{n}=\mathbf{4 0})\end{array}$ & P value \\
Mean \pm SD & Mean \pm SD & & \\
\hline Preoperative & $13.04 \pm 0.56$ & $12.57 \pm 0.80$ & $0.003^{* *}$ \\
Postoperative & $12.84 \pm 0.56$ & $11.23 \pm 1.00$ & $0.0001^{* * *}$ \\
Change & 0.20 & 1.34 & \\
Percent change & 1.54 & 10.73 & \\
\hline
\end{tabular}

Unpaired Student's 't' test

$* *=$ Significant $(\mathrm{P}<0.01), * * *=$ Significant $(\mathrm{P}<0.001)$
Table III shows the general characteristics of short term results of haemorrhoidectomy. Pain the postoperative period was a frequent phenomenon and it was seen in $12(30 \%)$ patients case group in the first week, whereas in control group it was in $19(47.5 \%)$ patients. In the second week, pain was observed in $6(15 \%)$ patients of case group but in control group it was in $15(37.5 \%)$ patients. In the first month, pain was observed in only $2(5 \%)$ patients in case group, whereas in control group it was in $6(15 \%)$ patients. In the second month, none of the patients in case group experienced pain in anorectum, but it was in $2(5 \%)$ patients in control group.

During defaecation, in 1st week, pain was experienced by $17(42.5 \%)$ patients in case group, but in control group, it was by $29(72.5 \%)$ patients. Pain during defaecation was present in $11(27.5 \%)$ patients in the 2 nd week in the case group, whereas in control group it was in $23(57.5 \%)$ patients. In the 1st month, pain during defaecation was present in only $3(7.5 \%)$ patients in case group, whereas in control group, it was in $11(27.5 \%)$ patients. In the 2 nd month, none of the case group of patients experienced pain during defaecation, but in control group, it was in $3(7.5 \%)$ patients.

Adaptation of edges sutured mucosa was good in 37 $(92.5 \%)$ patients in case group, whereas it was in only 14 $(35 \%)$ patients of control group. Adaptation in sutured mucosa was satisfactory in only $8(20 \%)$ patients in the case group, whereas it was $35(87.5 \%)$ in control group.

Acute retention of urine was a common complication of pelvic organ operation, especially with spinal anaesthesia. Haemorrhoidectomy was not escaped from this complication but it had decreased in the case group four times than control group. In case group, it was in $2(5 \%)$ cases, whereas it was in $8(20 \%)$ patients in control group due to placement of gauze tampon in anal canal.

Table III: General characteristics of short term results of haemorrhoidectomy.

\begin{tabular}{|c|c|c|c|c|}
\hline \multirow{2}{*}{$\begin{array}{l}\text { Character of } \\
\text { complications } \\
\text { during postoperative } \\
\text { period }\end{array}$} & \multirow[b]{2}{*}{$\begin{array}{l}\text { 1st week } \\
\text { No. }(\%)\end{array}$} & \multicolumn{2}{|c|}{ Case group $(n=40)$} & \multirow[b]{2}{*}{$\begin{array}{l}\text { 2nd month } \\
\text { No. }(\%)\end{array}$} \\
\hline & & $\begin{array}{l}\text { 2nd week } \\
\text { No. }(\%)\end{array}$ & $\begin{array}{l}\text { 1st month } \\
\text { No. }(\%)\end{array}$ & \\
\hline $\begin{array}{l}\text { Pain in operative } \\
\text { site (anorectum) }\end{array}$ & $12(30.0)$ & $6(15.0)$ & $2(5.0)$ & 0 \\
\hline $\begin{array}{l}\text { Pain in anorectum } \\
\text { during defaecation }\end{array}$ & $17(42.5)$ & $11(27.5)$ & $3(7.5)$ & 0 \\
\hline $\begin{array}{l}\text { Adaptation of edges } \\
\text { of sutured mucosa }\end{array}$ & 0 & $8(20.0)$ & 0 & 0 \\
\hline Good & 0 & $37(92.5)$ & 0 & 0 \\
\hline Retention of urine & $2(5.0)$ & 0 & 0 & 0 \\
\hline Perianal oedema & $2(5.0)$ & 0 & 0 & 0 \\
\hline Normalization of stool & 0 & $35(87.5)$ & $40(100.0)$ & 0 \\
\hline $\begin{array}{l}\text { Periodic bleeding at } \\
\text { defaecation }\end{array}$ & $2(5.0)$ & $1(2.5)$ & 0 & 0 \\
\hline \multirow{2}{*}{$\begin{array}{l}\text { Character of } \\
\text { complications } \\
\text { during postoperative } \\
\text { period }\end{array}$} & & \multicolumn{2}{|c|}{ Control group $(n=40)$} & \\
\hline & $\begin{array}{l}\text { 1st week } \\
\text { No. }(\%)\end{array}$ & $\begin{array}{l}\text { 2nd week } \\
\text { No. }(\%)\end{array}$ & $\begin{array}{l}\text { 1st month } \\
\text { No. }(\%)\end{array}$ & $\begin{array}{l}\text { 2nd month } \\
\text { No. }(\%)\end{array}$ \\
\hline $\begin{array}{l}\text { Pain in operative } \\
\text { site (anorectum) }\end{array}$ & $19(47.5)$ & $15(37.5)$ & $6(25.0)$ & $2(5.0)$ \\
\hline
\end{tabular}




\begin{tabular}{|c|c|c|c|c|}
\hline $\begin{array}{l}\text { Pain in anorectum } \\
\text { during defaecation } \\
\text { |Adaptation of edges } \\
\text { of sutured mucosa }\end{array}$ & $29(72.5)$ & $23(57.5)$ & $11(27.5)$ & $3(7.5)$ \\
\hline Satisfactory & 0 & $35(87.5)$ & 0 & 0 \\
\hline Good & 0 & $14(35.0$ & 0 & 0 \\
\hline Retention of urine & $8(20.0)$ & 0 & 0 & 0 \\
\hline Perianal oedema & $5(12.5)$ & $3(7.5)$ & $2(5.0)$ & 0 \\
\hline Normalization of stool & 0 & $25(62.5)$ & $35(87.5)$ & $40(100.0)$ \\
\hline $\begin{array}{l}\text { Periodic bleeding at } \\
\text { defaecation }\end{array}$ & $8(20.0)$ & $7(17.5)$ & $3(7.5)$ & $2(5.0)$ \\
\hline
\end{tabular}

Perianal oedema was a common complication of haemorrhoidectomy. From Table III, it is visible that this complication reduced three times in case group from control group. In case group, inflation of balloon reduced the perianal oedema to $2(5 \%)$ cases, but in control group, it was in $10(25 \%)$ cases.

Normalization of stool was in $35(87.5 \%)$ patients in 2nd week and in $40(100 \%)$ cases in the first month in the case group, whereas it was in $25(62.5 \%)$ in 2 nd week and in 40 $(100 \%)$ cases in 2 nd month in control group.

Periodic bleeding at defaecation was present in $3(7.5 \%)$ cases in up to 2 nd week of operation in case group, but it continued in $20(50 \%)$ cases from 2 nd week up to 2 nd month.

\section{Discussion}

Haemorrhoidectomy is the method of choice in bleeding haemorrhoids. The compressive method applied after completion of haemorrhoidectomy revealed the better results in comparison to haemorrhoidectomy alone. Long term compression in haemorrhoidal zones of anorectum results in the reduction of influx of blood on arteriolovenular anastomoses of cavernous bodies and simultaneous elimination of stagnation of blood in haemorrhoids. Therefore, the pressure in the lumen of cavernous bodies is reduced, they are drained and the lumen of cavernous bodies are collapsed. In addition to this, at pressure on haemorrhoids the nerve receptors are irritated, stimulates the contraction of muscles of anal sphincters, which even more magnifies compression on haemorrhoids and accelerates the process of collapse of walls of ecstatic vessels. There is an oxygen deficiency in tissues of haemorrhoids, the physicochemical properties of walls of pathologically changed vessels and their surrounding tissues are changed; stimulation of the development of young connective tissue and the process of cicatrization is magnified ${ }^{7}$.

The walls of pathologically changed vessels of haemorrhoids in connection with a long time compression and local hypoxia are squeezed, gradually scleroses, emptying of haemorrhoids and bleeding cases ${ }^{8}$.

The compression applied over the both internal and external haemorrhoidal zones are by the specially made compressive probe. The probe is designed as tri channeled rubber tube, one main lumen for a free passage of featus and other two channels the lumens of which are communicated with the functional end of two swelled latex cuffs, on the other end with monitoring balloons communicated with the main cuff. The size and shape of the probe corresponds to anatomical structure of anorectal area. Being grounded on the data of literature about values of internal pressure and own data (at creation of pressure higher than $50 \mathrm{mmHg}$ appearance of pain reaction) in both cuffs formed pressure equally 50 mmHg. This pressure, according to our data, provided compression on the haemorrhoidal zones and reduced activity of arterial influx in the areas of arteriolovenular anastomoses.

In the previous data, we found that the application of compressive method in the conservative method of treatment of bleeding haemorrhoids intended for stoppage of haemorrhoidal bleeding, lowering of activity of arteriolovenular anastomoses, normalization of microcirculation in cavernous bodies and thus it was effective as conservative treatment of bleeding haemorrhoids. The time was for 4 hours in a day and the process was repeated for 4-5 times in an interval of 1-4 days $^{7}$.

The application of compressive probe after surgical treatment of bleeding haemorrhoids was directed to stop the residual bleeding, restoration of blood flow and normalization of remaining cavernous bodies, adaptation of edges of sutured mucosa and to reduce the perianal oedema (shown in Table III). The time of application of compressive probe was for 24 hours after operation.

The compressive method in the haemorrhoidal zones after surgical treatment of bleeding haemorrhoids provided the elimination of stagnation of blood in the cavernous derivations resulting in fall and aseptic pasting together of their walls, sclerosis and shrinkage of haemorrhoidal clusters. Thus, it prevented the relapses of haemorrhoids. This method can be used as the conservative method of treatment for the bleeding haemorrhoids in those patients whose operative treatment is contraindicated. The long term effect of this method is also may be searched for.

\section{References}

1. Dultsev Yu V, Titov A Yu, Coauth. Haemorrhoidectomy with suturing apparatus. J Surg 1989;2:115-8.

2. Vorobeov GI, Glagodorni LA. Choice of methods of treatment of haemorrhoids. J Surg 1999;8:505.

3. Rivkin VL, Kapuller LL. Haemorrhoids, constipation. M Medpractice 2000;158.

4. Akopian Ea B, Nazarov L Yu. Surgical treatment of haemorrhoids. Bull Surg 1989;142:1136.

5. Stelzner F. Haemorrhoidectomy a simple operation? Incontinence, stenosis, fistula, infection and fatalities. Chirurg 1992;63:31626.

6. Standards Task Force-American Society of Colon and Rectal Surgeons. Practical parameters for the treatment of haemorrhoids. Dis Col Rect 1993;36:1118-20.

7. Digeshwar T. Compression method in the treatment of haemorrhoids [ $\mathrm{PhD}$ dissertation in medical science]. Moscow 1993.

8. Goldin Va, Degeshwar T. Modern method of treatment of bleeding haemorrhoids. In: Actual problems in clinical surgery (collection of works of Moscow Medical and Dental Institute after name of NA Semashka). Moscow 1993:94-7. 